\title{
An Awakening with Regional Archivists
}

\author{
Ebony S. McDonald \\ Louisiana State University
}

\begin{abstract}
An early career librarian of color reflects upon her attendance at a regional conference and how it related to her first rotation as part of a Diversity Residency Program at a large predominately white institution in the Deep South. She examines how the lack of diverse representation within librarianship has continually contributed to her own crisis of professional identity and how the residency program has influenced managing this crisis.
\end{abstract}

Author Bio: Ebony Sable McDonald is a native of Charlotte, North Carolina. She received her BA from the University of North Carolina at Charlotte and MSLS from the University of North Carolina at Chapel Hill. She currently works as the African and African-American Studies Diversity Librarian as part of the inaugural Diversity Residency Program at Louisiana State University in Baton Rouge, Louisiana.

Keywords: diversity, special collections, professional development

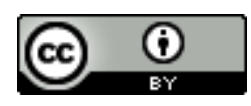

This is an Open Access article distributed under the terms of the Creative Commons Attribution 4.0 International License (http://creativecommons.org/licenses/by/4.0), which permits unrestricted use, distribution, and reproduction in any medium, provided the original work is properly cited. 
"Our responsibility is to hold up a mirror for mankind." - Michelle Light, Director of Special Collections Directorate at the Library of Congress

In May, I attended the 2019 Conference of Inter-Mountain Archivists (CIMA) \& Society of Southwest Archivists (SSA) Joint Annual Meeting in Tucson, Arizona. It is a regional meeting of archives and special collections professionals primarily from Arizona, Arkansas, Idaho, Louisiana, Oklahoma, Nevada, New Mexico, Texas, and Utah. This meeting introduced me to a host of diversity issues that permeate archival work through its theme of "Crossing Borders, Blazing Trails." The timing of this meeting came on the heels of my completion of the first rotation in Special Collections (SC) and start in the second in Digital Programs and Services (DPS), both of which were part of my participation in Louisiana State University (LSU) Libraries' inaugural Diversity Residency Program. The intent of attending this meeting was to conceptually bridge the two departments, but it did more than that.

In her Plenary Address, Michelle Light, the new Director of Special Collections Directorate at the Library of Congress, highlighted the borders and boundaries of archival practice that enable western hegemony and a self-serving agenda that gives prominence to stories of the powerful. She detailed her own process for confronting her white fragility and gave three examples of when her lack of selfawareness about her own cultural lens as a white American complicated her relationships with donors from marginalized communities. She then advised placing more emphasis on human connections with donors rather than emphasizing comparative deficiencies of other potential repositories. She implored attendees to build their skills in cultural competency and to recognize that race and ethnicity matter when conducting multicultural outreach, as they have a significant impact on the power dynamics of donor relations. Finally, she urged white attendees to build self-awareness of their own white fragility 
and skills in cultural competency, but without adding another source of emotional labor to their colleagues of color. In her closing, she reminded everyone of the importance of archives, whose work serves to keep society accountable.

After hearing her address, I sat in my seat completely stunned but also appreciative. I had not expected such a meeting to open with an acute message petitioning for more personal humility, particularly in a profession I had perceived in some ways as elitist and exclusive. In spite of the immense support that I have received from the SC team and LSU Libraries faculty and staff, I found myself disconnected from the initial tasks of my first rotation and internally conflicted about whether the work was meaningful to me. Sure, there also was the emotional discomfort that comes with learning a new job, institution, and city that impacted my initial ability to consciously buy-in to the work (way more than I anticipated). Yet while I had been able to appreciate all of the new skills that I have acquired, there was still an undeniable internal resistance to seeing a future for myself as an archivist or in SC in general. I applauded Light for so precisely articulated a looming question that I could not shake at the beginning of my SC rotation: does this work actually serve people like me?The point of this residency is to discover a professional path for myself as an academic librarian, but if / cannot connect to the work that I am doing, then will this work ultimately be suited for me?

The majority of stories that are preserved and made available by large, predominately white institutions such as LSU are generally not stories to which I, as a person of color in a profession with significant diversity issues, can relate. I could not see myself in the service that I would be providing. I had no idea that relating to my work on that level was even important to me as a professional (which in some way meant that the Residency Program was fulfilling its intended purpose). It was a relief to hear 
this "Gospel" from one of the leading authorities in the profession rather than feel I was somehow being ungrateful for the opportunity the program presented to me.

The fact that I connected so deeply to what Light said meant that her words felt less like a social justice warrior's virtue signaling and more like a hard truth that needed to be acknowledged (and by someone of her status nonetheless). I definitely felt a change in myself after her talk regarding my relationship with the work that I had been doing my first 90 days at LSU. As I continue to reflect upon this meeting and my experience at LSU Libraries thus far, I suppose there is one lingering question: can I actually see a professional future for myself in archives or SC?

Well, yes.

As Light pointed out, it is not on one group to make a change for the expansion of this profession to be more inclusive and reflective of the communities that they service but also on those who wish to see themselves represented to continue to be involved and recruit others in order to advocate for more counterhegemonic stories to be told. Change is an equal effort. While it feels like a huge weight to figuratively carry a torch as a representative of non-dominant group when considering participation in a profession, it also could be an immense honor to see the impact that one's presence has made on change.

I still cannot say for sure what path I will pursue in academic libraries (or if I will stay even in academia) after the conclusion of this residency program. What I can say is that finding my professional identity has been an interrogative process that is currently being informed by the professional development opportunities of the program. These opportunities, such as this meeting, will not only continue to inform new understandings of my potential role within this ever evolving profession but also have begun to answer the intermittent questions of belonging to it that I, now as an early career 
librarian of color, have struggled with since library school. In spite of these questions, I still want to continue to move forward in librarianship as long as it continues to do the same with addressing its equity, diversity, and inclusion issues.

\section{References}

Light, M. (2019, May 16). Plenary Address. Speech given at 2019 Conference of Inter-Mountain Archivists \& Society of Southwest Archivists Joint Annual Meeting, Tucson, AZ.

McDonald, E. (2019, June 11). Resident reflects: An awakening with regional archivists [Blog post]. Retrieved from http://news.blogs.lib.lsu.edu/2019/06/11/resident-reflects-an-awakening -with-regional-archivists 